


\section{1oolf 2iajt}

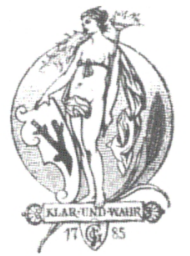

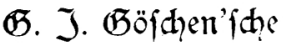

Derlagshanduna

$\$$ 


\section{Grottbolo Ephraim Leining'z}

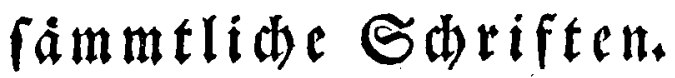

Siebenter Banb.

\section{$\mathfrak{B} \in \mathfrak{l} \mathfrak{n}$.}

Jn o

1825 . 
